\title{
Implementasi Blended Learning pada Era Digital dan Kemandirian Belajar Mahasiswa Pendidikan Matematika
}

\author{
T Rohaeti, ,,a D Lusiyana ${ }^{2, b}$ \\ ${ }^{1,2}$ Pendidikan Matematika, FKIP, Universitas Muhammadiyah Cirebon \\ Jl. Fatahillah No. 40 Watubelah Sumber Cirebon, Jawa Barat \\ e-mail: ${ }^{a}$ titi.rohaeti@umc.ac.id, bdesylusiyana@gmail.com
}

\begin{abstract}
This study aims to describe the tendency of mathematics education students' independence after the implementation of blended learning in the learning process in digital era. The method used is descriptive quantitative with the data analysis using percentages. The subject in this study is the 4th Semester Mathematics Education Students in Mathematics Learning Strategy course. The data collection in this study used a questionnaire with a Likert scale. The results shows that the total respondents' answers regarding the tendency of student learning independence when applied blended learning is $83.85 \%$ which is in the very positive category.
\end{abstract}

Keywords: Blended learning, students' independence, digital era

\begin{abstract}
Abstrak
Penelitian ini bertujuan untuk mendeskripsikan kecenderungan kemandirian mahasiswa pendidikan matematika setelah implementasi blended learning dalam proses pembelajaran dalam era digital. Adapun metode yang digunakan yaitu kuantitatif deskriptif dengan analisa data menggunakan prosentase. Subjek penelitiannya yaitu mahasiwa Pendidikan Matematika Semester 4 pada Mata Kuliah Strategi Pembelajaran Matematika. Pengumpulan datanya dengan angket kuesioner menggunakan skala likert. Hasil penelitian menunjukkan bahwa total jawaban responden mengenai kecenderungan kemandirian belajar mahasiswa saat diterapkan blended learning adalah sebesar $83,85 \%$ yaitu berada pada kategori sangat positif.
\end{abstract}

Kata kunci: Blended Learning, Kemandirian, Era Digital 


\section{PENDAHULUAN}

Pembelajaran di era digital berbeda dengan era dulu. Pada era digital kehidupan manusia tidak bisa terlepas dari perangkat yang serba elektronik. Penggunaan elektronik tersebut menjangkau seluruh aspek manusia termasuk pendidikan. Menurut Setiawan [1] pendidikan harus menjadi media utama untuk memahami, menguasai, dan memperlakukan teknologi dengan baik dan benar. Sekarang pembelajaran dapat dilakukan tanpa harus selalu tatap muka. Sehingga mahasiswa dapat belajar tanpa mengenal batas baik dari waktu atau tempat. Mahasiswa dituntut untuk cakap, kreatif, dan mandiri Hal ini sesuai dengan tujuan pendidikan tinggi.

Tujuan dari pendidikan tinggi diantaranya adalah mengembangkan potensi mahasiswa agar menjadi manusia yang cakap, kreatif, mandiri, serta menguasai cabang ilmu pengetahuan dan teknologi. Keempat potensi tersebut menjadi satu kesatuan yang harus dimiliki oleh mahasiswa. Hal ini termuat dalam undang-undang RI nomor 12 tahun 2012. Undang-undang tersebut menyatakan bahwa pendidikan tinggi diselenggarakan dengan prinsip antara lain pembelajaran yang berpusat pada mahasiswa [2]. Dosen bukan lagi satu-satunya sumber belajar. Keterbatasan pada sistem konvensional seharusnya sudah tidak ditemukan lagi.

Pada pendidikan tinggi yang masih menggunakan pembelajaran konvensional ditandai dengan adanya tatap muka di kelas, artinya dalam pembelajaran ini terikat ruang dan waktu, atau dengan kata lain dosen dan mahasiswa harus berada pada ruang dan waktu yang sama. Adapun kelemahan dari pembelajaran konvensional yaitu sebagian mahasiswa tidak punya budaya belajar tanpa bimbingan dan kehadiran dosen [3]. Sehingga budaya mandiri dalam melakukan pembelajaran berkurang. Masih banyak mahasiswa yang melakukan cara belajar tidak efektif. Tetapi di era digital ini proses pembelajaran antara dosen dan mahasiswa dapat dilakukan kapan saja, dimana saja, dan melalui berbagai macam sumber belajar yang dapat diakses kapan 
saja. Pembelajaran seperti ini dapat dilakukan melalui langkahlangkah pada salah satu model pembelajaran. Salah satu Model pembelajaran yang dapat digunakan sistem tanpa batas tersebut yaitu blended learning.

Pengertian dari Blended Learning adalah penggabungan pembelajaran e-learning dengan pembelajaran tatap muka (face-toface) yang menggunakan media pembelajaran serta teori-teori pembelajaran dalam proses pembelajaran [4]. Artinya perpaduan antara tatap muka dalam kelas dan melalui kelas dalam jaringan. Pada sistem pembelajaran dalam jaringan dibutuhkan LMS atau website sebagai salah satu media pembelajaran.

Blended learning merupakan salah satu dari tiga prinsip pembelajaran yang terdapat pada perguruan tinggi. Ketiga prinsip tersebut adalah web-based learning yaitu pembelajaran berbasis website, problem-based learning yaitu pembelajaran berbasis masalah, dan collaborative learning yaitu pembelajaran kolaborasi. Blended learning termasuk dalam prinsip web-based learning karena terdapat pembelajaran berbasis internet atau pembelajaran online [5]. Pembelajaran yang dilakukan yaitu menggunakan akses internet sebagai salah satu fasilitas belajar.

Menurut Uwes [6] pembelajaran blended adalah model pembelajaran yang menggabungkan antara strategi sinkron dan asinkron sebagai upaya menciptakan pengalaman belajar seoptimal mungkin untuk mencapai hasil pembelajaran yang diharapkan. Tujuan yang paling utama yaitu kemandirian. Tetapi selain kemandirian terdapat tujuan lain dari blanden learning. Tujuan blended learning yaitu untuk mengoptimalkan kegiatan pembelajaran menjadi lebih baik, memfasilitasi karakteristik dan kemandirian belajar mahasiswa. Kemandirian terbentuk karena mahasiswa belajar sendiri tanpa diawasi langsung oleh dosen. Walaupun pembelajaran blanded learning memiliki memiliki banyak kelebihan tetapi Blended learning tidak sepenuhnya menggantikan pembelajaran tatap muka. Tatap muka dibutuhkan pada pembelajaran menggunakan blanded learning. 
Blended learning hanya mendukung dan melengkapi materi yang belum tersampaikan pada saat pembelajaran di kelas [6].

\section{METODE PENELITIAN}

Tujuan dari penelitian ini yaitu untuk menjelaskan kecenderungan kemandirian belajar pada mahasiswa pendidikan matematika universitas Muhammadiyah Cirebon setelah dilakukan implementasi blended learning dalam proses pembelajaran pada mata kuliah Strategi Pembelajaran Matematika. Metode penelitian yang dilakukan yaitu kuantitatif deskriptif dengan analisa data menggunakan prosentase. Subjek penelitian ini yaitu mahasiwa Pendidikan Matematika Semester 4 yang berjumlah 11 mahasiswa yang berlokasi di Universitas Muhammadiyah Cirebon. Pengumpulan data dilakukan dengan menyebarkan angket dengan menggunakan skala likert. Indikator kemandirian belajar mahasiswa mengacu pada indikator yang dikembangkan oleh Kana Hidayati dan Endang Listyani [7]. Terdapat enam indicator yang dikembangkan yaitu: 1) Ketidaktergantungan terhadap orang lain, 2) Memiliki kepercayaan diri, 3) Berperilaku disiplin, 4) Memiliki rasa tanggung jawab, 5) Berperilaku berdasarkan inisiatif sendiri, dan 6) Melakukan kontrol diri. Keenam indikator tersebut jadikan sebagai acuan untuk membuat intrumen penelitian. Ketentuan skala persentase yang digunakan untuk menyimpulkan data hasil penelitian dapat dilihat pada tabel sebagai berikut [6].

Table 1. Kriteria Interpetasi Skor

\begin{tabular}{ccc}
\hline No. & Rentang Skor (\%) & Kategori \\
\hline 1 & $76-100$ & Sangat positif \\
2 & $51-75$ & Positif \\
3 & $26-50$ & Negatif \\
4 & $1-25$ & Sangat negatif \\
\hline
\end{tabular}




\section{HASIL DAN PEMBAHASAN}

Analisis data pada penelitian ini mengacu pada indikator kemandirian belajar mahasiswa. Jumlah responden yaitu mahasiswa pendidikan matematika semester 4 tahun pelajaran 2018/2019, berikut peneliti sajikan pada tabel di bawah ini:

Table 2. Kecenderungan Kemandirian Belajar Mahasiswa Pendidikan Matematika

\begin{tabular}{|c|c|c|c|c|c|}
\hline No. & Indikator & $\begin{array}{l}\text { Skor } \\
\text { ideal }\end{array}$ & $\begin{array}{l}\text { Skor } \\
\text { aktual }\end{array}$ & Prosentase & Kategori \\
\hline 1 & $\begin{array}{l}\text { Ketidaktergantungan } \\
\text { terhadap orang lain }\end{array}$ & 260 & 212 & $81,54 \%$ & Sangat positif \\
\hline 2 & $\begin{array}{c}\text { Memiliki } \\
\text { kepercayaan diri }\end{array}$ & 195 & 159 & $81,54 \%$ & Sangat positif \\
\hline 3 & Berperilaku disiplin & 195 & 166 & $85,13 \%$ & Sangat positif \\
\hline 4 & $\begin{array}{c}\text { Memiliki rasa } \\
\text { tanggung jawab }\end{array}$ & 195 & 170 & $87,18 \%$ & Sangat positif \\
\hline 5 & $\begin{array}{c}\text { Berperilaku } \\
\text { berdasarkan inisiatif } \\
\text { sendiri }\end{array}$ & 260 & 213 & $81,92 \%$ & Sangat positif \\
\hline \multirow[t]{2}{*}{6} & $\underset{\text { diri }}{\text { Melakukan kontrol }}$ & 195 & 170 & $87,18 \%$ & Sangat positif \\
\hline & Total & 1300 & 1090 & $83,85 \%$ & Sangat positif \\
\hline
\end{tabular}

Berdasarkan tabel di atas, diperoleh prosentase total responden menjawab mengenai kecenderungan kemandirian belajar setelah dilakukan pembelajaran menggunakan blended learning adalah sebesar 83,85\%. Nilai tersebut berada pada kategori sangat positif. Adapun rincian tiap indikatornya adalah sebagai berikut. Berdasarkan analisis data dari tabel 2 diperoleh prosentase kemandirian belajar pada indikator ketidaktergantungan terhadap orang lain sebesar 81,54\%. Berdasarkan hasil perolehan terebut dapat diartikan bahwa secara umum kemandirian belajar mahasiswa dalam indikator ketidaktergantungan terhadap orang lain dikategorikan sangat positif. 


\section{Hipotenusa}

Journal of Research Mathematics Education VOL.3 NO.1 2020

Berdasarkan hasil penelitian diperoleh sebagian besar mahasiswa yang mengikuti pembelajaran pada mata kuliah Strategi Pembelajaran Matematika menggunakan blended learning memiliki kertidaktergantungan pada orang lain.

Berdasarkan analisis data dari tabel 2 diperoleh prosentase kemandirian belajar pada indikator memiliki kepercayaan diri sebesar $81,54 \%$, yang dapat diartikan bahwa secara umum kemandirian belajar mahasiswa pada indikator memiliki kepercayaan diri termasuk dalam kategori sangat positif. Berdasarkan hasil penelitian menunjukkan bahwa sebagian besar mahasiswa yang mengikuti pembelajaran pada mata kuliah Strategi Pembelajaran Matematika dengan mengaplikasikan blended learning memiliki kepercayaan diri.

Berdasarkan analisis data dari tabel 2 diperoleh prosentase kemandirian belajar pada indikator berperilaku disiplin yaitu sebesar $81,13 \%$, yang dapat diartikan bahwa secara umum kemandirian belajar pendidikan mahasiswa dalam indikator berperilaku disiplin termasuk dalam kategori sangat positif. Sehingga dapat disimpulkan berdasarkan hasil penelitian menunjukkan bahwa sebagian besar mahasiswa yang mengikuti pembelajaran pada mata kuliah Strategi Pembelajaran Matematika dengan blended learning memiliki perilaku disiplin.

Berdasarkan analisis data dari tabel 2 diperoleh prosentase kemandirian belajar pada indikator memiliki rasa tanggungjawab sebesar $87,18 \%$. Besar prosentase tersebut menunjukkan bahwa secara umum kemandirian belajar pendidikan mahasiswa dalam indikator memiliki rasa tanggungjawab termasuk dalam kategori sangat positif. Hasil penelitian menunjukkan bahwa sebagian besar mahasiswa yang mengikuti pembelajaran pada mata kuliah Strategi Pembelajaran Matematika dengan blended learning memiliki memiliki rasa tanggungjawab.

Berdasarkan analisis data dari tabel 2 diperoleh prosentase kemandirian belajar pada indikator berperilaku berdasarkan inisiatif sendiri yaitu sebesar $81,92 \%$. Besar prosentase tersebut menunjukkan 


\section{Hipotenusa}

Journal of Research Mathematics Education VOL.3 NO.1 2020

bahwa secara umum kemandirian belajar pendidikan mahasiswa dalam indikator berperilaku berdasarkan inisiatif sendiri termasuk dalam kategori sangat positif. Sehingga dapat disimpulkan Hasil penelitian menunjukkan bahwa sebagian besar mahasiswa yang mengikuti pembelajaran pada mata kuliah Strategi Pembelajaran Matematika dengan blended learning berperilaku berdasarkan inisiatif sendiri.

Berdasarkan analisis data dari tabel 2 diperoleh prosentase kemandirian belajar pada indikator melakukan kontrol diri yaitu sebesar 87,18\%. Besar prosentase ini menunjukkan bahwa secara umum kemandirian belajar pendidikan mahasiswa dalam indikator melakukan kontrol diri termasuk dalam kategori sangat positif. Hasil penelitian menunjukkan bahwa sebagian besar mahasiswa yang mengikuti pembelajaran pada mata kuliah Strategi Pembelajaran Matematika dengan blended learning melakukan kontrol diri. Sejalan dengan pendapat Chambers (dalam Sucipto, 2017), menjelaskan bahwa blended learning memberikan peluang kepada mahasiswa untuk menjalani proses belajar aktif dengan melakukan regulasi diri, mengontrol sendiri proses pembelajaran yang dilakukan, menumbuhkan motivasi diri, dan mengembangkan kepercayaan diri, serta memilih atau mengatur sendiri lingkungan belajarnya untuk mendukung keefektifan belajar yang mencakup lingkungan fisik dan nonfisik. (Sucipto, 2017)

\section{KESIMPULAN DAN SARAN}

Berdasarkan hasil penelitian implementasi blended learning pada mata kuliah Strategi Pembelajaran Matematika dan kemandirian belajar mahasiswa pendidikan matematika di Universitas Muhammadiyah Cirebon, diperoleh persentase hasil kemandirian belajar dari 6 indikator yaitu : 1) ketidaktergantungan terhadap orang lain sebesar $81,54 \%$ dikategorikan sangat positif, 2) memiliki kepercayaan diri sebesar $81,54 \%$ dikategorikan sangat positif, 3) berperilaku disiplin sebesar 85,13\% dikategorikan sangat positif, 4) 


\section{Hipotenusa}

Journal of Research Mathematics Education

VOL.3 NO.1 2020

memiliki rasa tanggung jawab sebesar $87,18 \%$ dikategorikan sangat positif, 5) berperilaku berdasarkan inisiatif sendiri sebesar $81,92 \%$ dikategorikan sangat positif, dan 6) melakukan kontrol diri sebesar $87,18 \%$ dikategorikan sangat positif. Sedangkan secara keseluruhan jawaban responden mengenai kecenderungan kemandirian belajar mahasiswa saat diterapkan blended learning adalah sebesar 83,85\% yaitu berada pada kategori sangat positif. Sehingga dapat disimpulkan bahwa kecenderungan kemandirian belajar mahasiswa yaitu mahasiswa memiliki kemadirian belajar yang positif. Mahasiswa tidak tergantung terhadap orang lain, mereka cenderung lebih mandiri dalam segala hal. Pembelajaran menggunakan blanded learning mendukung kemandirian belajar mahasiswa yang cenderung sangat positif. Saran dari peneliti yaitu hendaknya pengajar dan mahasiswa memperhatikan dukungan teknologi dan koneksi internet yang memadai sehingga dapat memperlancar implementasi blended learning dalam proses pembelajaran. Selain itu, pengajar juga perlu mempertimbangkan faktor biaya dengan memanfaatkan tawaran aplikasi yang bebas biaya di internet sehingga tidak perlu membangun sistem informasi yang kompleks sendiri.

\section{PENGHARGAAN}

Penelitian ini didukung oleh Belmawa (Direktorat Jenderal Pembelajaran dan Kemahasiswaan) - Kemenristekdikti, yang merupakan luaran dari program PDS 2019 dalam perkuliahan di LPTK. 


\section{DAFTAR PUSTAKA}

[1] Setiawan, W. (2017). Era Digital dan Tantangannya. Seminar Nasional Pendidikan 2017, 1-9.

[2] Fitriasari, P., \& Sari, N. (2017). Implementasi Blended Learning Untuk Meningkatkan Kemandirian Belajar Mahasiswa Pada mata Kuliah Metode Numerik. Seminar Nasional Matematika dan Aplikasinya. Surabaya: Universitas Airlangga

[3] Sucipto, S. (2017). Peningkatan Self Regulated Learning Mahasiswa Di Era Digital Melalui Pembelajaran Blended Learning. Soulmath, 5(1), 31. https://doi.org/10.25139/sm.v5i1.455

[4] Wardani, D. N., Toenlioe, A. J., \& Wedi, A. (2018). Daya tarik pembelajaran di era 21 dengan Blended Learning. Jurnal Kajian Teknologi Pendidikan, 1(1), 13-18.

[5] Taradi, S. K., Taradi, M., Radić, K., \& Pokrajac, N. (2005). Blending problem-based learning with Web technology positively impacts student learning outcomes in acid-base physiology. American Journal of Physiology - Advances in Physiology Education, 29(1), 35-39. https://doi.org/10.1152/advan.00026.2004

[6] Al Aslamiyah, T., Setyosari, P., \& Praherdhiono, H. (2019). Blended Learning dan Kemandirian Belajar Mahasiswa Teknologi Pendidikan. Jurnal Kajian Teknologi Pendidikan, 2(2), 109-114.

[7] Hidayati, K., \& Listyani, E. (2010). IMPROVING INSTRUMENTS OF STUDENTS' SELF-REGULATED LEARNING Kana Hidayati and Endang Listyani FMIPA UNY Mathematics Education Department. Retrieved from http://staff.uny.ac.id/sites/default/files/penelitian/Kana Hidayati, M.Pd./Pengembangan Instrumen.pdf 